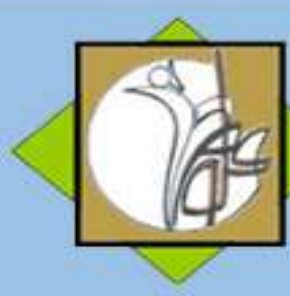

Research Article

\title{
The Effect of Generic and Non-generic Feedback on Basketball Free Throw Learning in Children
}

\author{
Masoumeh Rahimizadeh ${ }^{1}$, Mehdi Shahbazi ${ }^{2}$ \\ 1. Masoumeh Rahimizadeh, (MA) University of Tehran, Tehran, Iran. \\ 2. Mehdi Shahbazi, (Ph. D) University of Tehran, Tehran, Iran.
}

\section{ARTICLE INFO}

Received November 2017

Accepted October 2018

\section{KEYWORDS:}

Basketball free throw, Girl \& Boy, Children, Generic Feedback, Non-generic feedback

CITE:

Rahimizadeh, Shahbazi . The Effect of Generic and Nongeneric Feedback on Basketball Free Throw Learning in Children, Research in Sport Management \& Motor Behavior, 2021: 11(21):

44-55

d. 10.52547/JRSM.11.21.44

\section{ABSTRACT}

Non-generic feedback refers to a specific event and that task performance is the reason to the acquisition of skills and implies that performance is malleable, while generic feedback implies that task performance reflects an inherent ability. The Goal of this study was to determine the generic and nongeneric feedback effects on children's motor learning basketball free throw. This research was semi-experimental. For this purpose, sixty children of Tehran ( 30 girls and 30 boys) aged $9-13$ years participated in the study and were randomly divided into four groups of 15 individuals. Subjects performed six basketballs free throw in the acquisition (Two blocks of three trials). Which after the third throw, according to the group of subjects received a positive feedback (generic or non-generic) and also after the Sixth throw, negative feedback. After half an hour was immediate retention in the same way. Data were analyzed by using two-way ANOVA and repeated measures. Results showed that non-generic feedback was significantly more effective than generic feedback and shows more improvement in Performance. The present results demonstrate the importance of the wording of feedback, although these terms might not have an immediate effect on performance but by enhance motivation, poor performance is purportedly. 


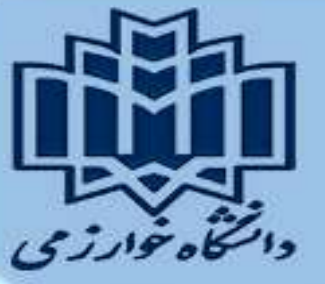

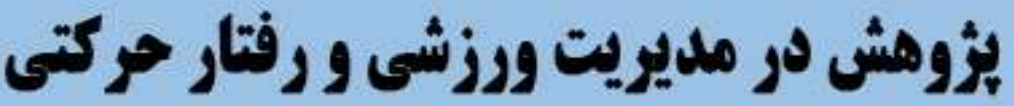

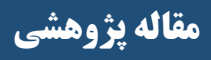

\section{تأثير بازخورد عام و خاص بر يادكيرى يرتاب آزاد بسكتبال در كودكان}

\author{
معصومه رحيمى زاده'،مهلى شهبازى'” \\ 1. كارشناسى ارشد رفتار حركنى دانشكده تربيت بدنى و علوم ورزشى، دانشگاه تهران، تهران، ايران

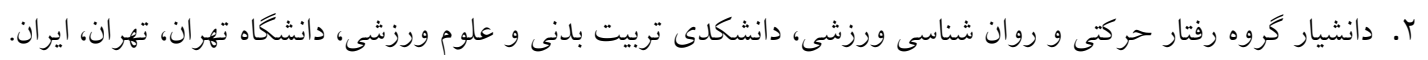

\section{جكيده}

بازخورد خاص به يكى رويداد خاص، اجراى تكليف به دليل قابليت اكتساب مهارت و عملكرد

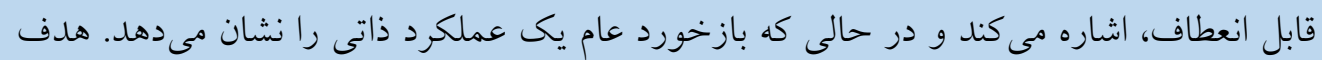

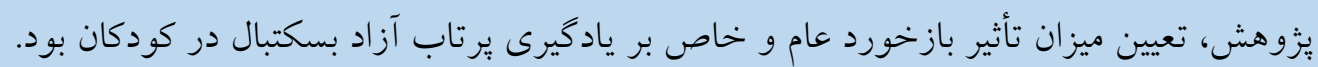

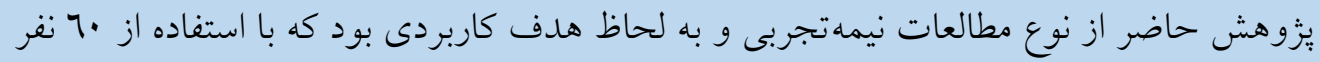

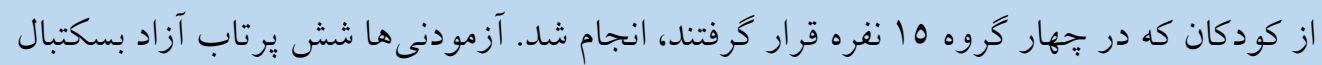

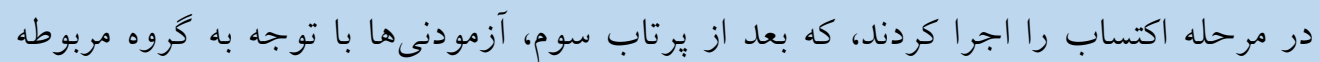

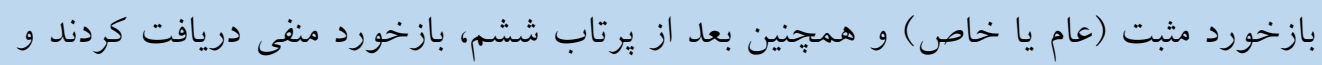

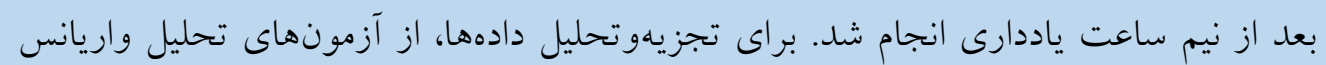

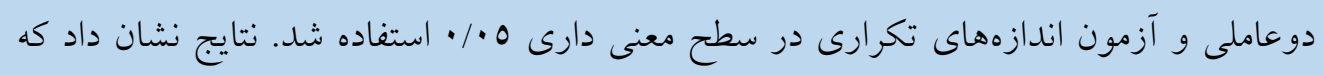
بازخورد خاص در هر دو گروه نسبت به بازخورد عام به ميزان معنى دارى مؤثرتر بوده و موجب داري

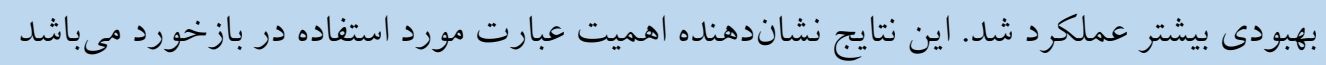

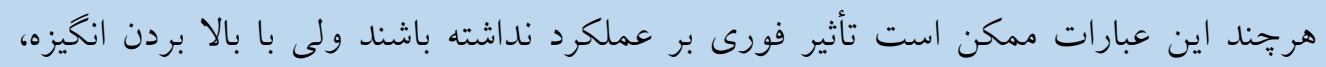
عملكرد ضعيف را بهبود مى دهد.
\end{abstract}

اطلاعات مقاله:

دريافت مقاله آبان 97هب

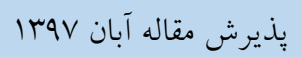

ثقونويسنده مسئول: shahbazimehdi@ut.ac.ir

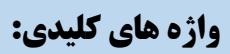
بازخورد عام، بازخورد خاص،

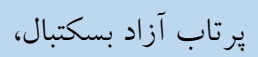
يُسر و دختر، كودكان ارجاع: رحيمى زاده، شهبازى. تأثير بازخورد

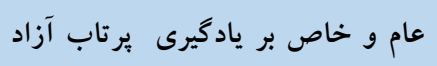

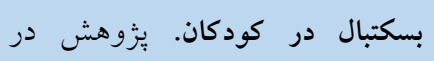

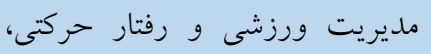
$\varepsilon \varepsilon-00:(Y)) 1: 1 \varepsilon \ldots$ 
به دليل اهميت يادگيرى در زندگى انسان، ئزوهشگرانى كه براى درى قو انين يادكيرى تلاش مى كند سوالات مختلفى را روبروى خود مىبينند، كه با روشهاى معتبر علمى به دنبال يافتن ياسخ براى اين سوالات هستند. هدف همه اين تلاشها، براى يافتن روشهاى بهتر در امر يادكيرى انسان است. همانطور كه مىدانيم معلم يا مربى مىتواند اطلاعاتى را در اختيار فراخير قرار دهد كه به تنهايى قادر به تشخيص آنها نيست. بدين ترتيب در فرآيند آموزش و يادكيرى بين مربى و فراگير يكى رابطه متقابل صورت مى گيرد( (1). اخر بتوانيم سازماندهى يك تجربه را در فرآيند يادكيرى از بعد زمانى مورد توجه قرار دهيم، شايد سه نوع اقدام قابل تقسيمبندى باشد؛ اقدامهاى قبل از عمل، حين عمل و يس از عمل. اقدامهاى قبل از عمل؛ شامل كليه طرحها و نقشههايى است كه براى ارائه ايده حركتى به آموزنده انجام مى گيرد؛ از جمله برانخيختن ياد كيرنده، ار ائه دستورات آموزشى و نمايش مهارت. اقدامهاى حين عمل كليه فعاليتهايى هستند كه توسط خود يادكيرنده و مربى در راستاى اجر ایى خود مهارت انجام مى گيرند؛ مانند تمرين بدنى به اشكال مختلف، تمرين ذهنى و راهنمايى بدنى و ارائٔ بازخورد. اقدامهاى يس از عمل به تدابير و فعاليتهايى كفته مىشود كه بار ديخر توسط خود آموزنده يا مربى براى ارزيابى آنجه انجام شده و با استفاده از تجربه آن براى كوشش بعدى صورت مى گيرند، مانند تشخيص خطا و ارائهُ بازخورد، اين اقدامها در شرايط عملى انتقال تجربأه يادكيرى را به يك آموزنده يا به يك كلاس آموزشى به حد بهينهُ خود افزايش مىدهد(Y). بازخورد، اطلاعات جامعى براى بهبود يادگيرى بعد از هر كوشش يا گروهى از كوششها است و اشاره به الكو و نتيجه حركات آنها دارد و به عنوان يكى از مهمترين و مؤثرترين عوامل مطالعه يادكيرى مهارت حركتى مطرح شده است(r). در بسيارى از مهارتهاى حركتى، كيرندهاى درونى بدن اطلاعاتى را در مورد حركت انجام شده براى فرد فراهم مى كنند(بازخورد درونى ') ولى در بعضى مهارتهاى حركتى اطلاعاتى از اجرا و نتيجه رفتار براى فرد فراهم نمى شود و يا اين اطلاعات ناجيز است. بر اين اساس براى ادامه ياد گيرى اطلاعاتى كه براى اين امر سودمند هستند را مىتوان از طريق وسايل كمك آموزشى، معلم و ... در اختيار نو آموز قرار داد(ع). نظريه آدامز ( (9VI) درباره جخكونكى عملكرد بازخورد به اين صورت بود؛ ارائه يىدريى، سريع و دقيق بازخورد، يادكيرى مهارت حركتى را افزايش مىدهد. ״را كه براى اجرا در مرحله فراگيرى مؤثرتر است و تصوير ذهنى آزمودنى را با مرتبط كردن هر ياسخ به هدف تقويت

مى كند (0) (0)

ثورندايك در تحقيقات خود تأثير بازخورد بر يادگيرى را از طريق قانون تجربى أثر ب(قانون كيرايى) بيان مىكند. اين قانون را كاهى اصل خوشايندى و ناخوشايندى نيز مىنامند. اين قانون بيان مىدارد، پاسخى كه نتيجه خوشايند و لذت بخش

1. internal feedback

2 . Empirical law of effect

https://jrsm.khu.ac.ir/ 
دارد، مطلوب فرد است و او خواستار تكرار آن است و همين امر موجب آموختن سريع آن مىشود، اما اخر نتيجهاش ناخوشايند باشد، به احتمال زياد از آموختن آن سر باز مىزند. به نظر ثورندايك مهمترين قانون يادكيرى همين قانون كيرايى است. اين قانون به لحاظ يادكيرى متضمن موفقيت و تجربههاى با معنى و ثمربخش براى شاكردان است(4). يكى ديخر از بحثهاى مهم بين متخصصان درباره محتواى بازخورد، اين است كه آيا بازخورد افزوده بّايد شامل اطلاعاتى در مورد صحت اجراى مهارت باشد يا خطاى آن. به اين دليل كه بازخورد افزوده در فرآيند يادگيرى نقشهاى متفاوتى دارد، ياسخ دادن به اين سوال دشوار است. از طرفى مربى مىتواند براى تأثير گذارى بر درى فرد بر ميزان تو انايىاش در اجراى مهارت از بازخورد افزوده استفاده كند. شواهد حمايت كننده از تأثير انخيزشى بازخورد كلامى در ادبيات خودكفايى و اجراى مهارت يافت مىشود. وقتى مربى به شاگرد مى گويد كه كدام جنبه را صحيح اجرا كرده است (بازخورد بس از كوشش خوب)، باخورد افزوده بيشتر نقش انخيزشى را بازى مى كند. از سوى ديخر، وقتى مربى اطلاعاتى در مورد خطا (بازخورد يس از كوشش ضعيف) مى دهل، بازخورد افزوده در نقش اطلاعاتى عمل مى كند(Y). شواهد يزوهشى تاكنون نشان داده بودند كه، اطلاعات مربوط به خطا، براى بيشرفت اجرا مؤثرتر است. اما تحقيقات اخير نظرى متفاوت را بيان داشته و اظهار مى كنند، ارائه بازخورد بِ از كوششهاى خوب تأثير بيشترى بر مهارتهاى حركتى دارند. اين تحقيقات نشان دادند آزمودنى به دنبال دريافت بازخورد مثبت، اهداف سطح بالاترى را انتخاب كرده كه اين امر مىتواند در يادكيرى و عملكرد حركتى آنها سودمند باشد(7). جِندين مطالعه در مسيرهاى مختلف بزّوهشى، از جمله رفتار مربيان(V, ^)، خود

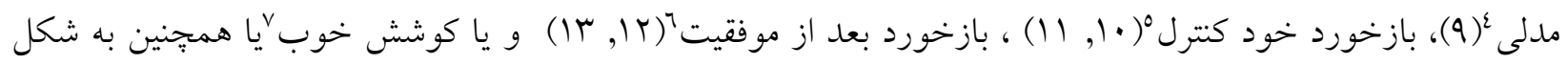
مقايسه با جامعه مثبت ^عا, 10)، نشان دادند كه بازخورد مىتواند از طريق خواص انخيزشى خود روى يادگيرى تأثير بحذارد(7 (1). بازخورد انخيزشى، در ارتباط با توانايى افراد مطرح شد. با در نظر كرفتن ساختارهاى دانشى كه شامل عقايدى در مورد توانايى ذاتى يا ويزّىىهايى غير قابل تغيير بود، مفهوم توانايى تبديل به فاكتور مهمى از عملكرد و يادگيرى در حوزه شناختى_اجتماعى شد(V) ال. به طور كلى، مطالعات نشان دادند كه بزركسالان و نيز كودكان با توجه به ديدكاههاى مختلف بركرفته شده از مفهوم توانايى، مى توانند به يك اندازه براى اجرا تحريك شوند. اين ديدكاهها مىتواند توانايىها را به عنوان : ظرفيت ثابت (نظريه بردازان ذاتى ه)، در اين نظريه محدوديتهايى براى بيشرفت تعيين مى شود يا مهارتهاى قابل انعطاف ( نظريه بردازان تكاملى “')، كه قابل ويشرفتند و وابسته به تلاش و يادكيرى در اين راه است(1/, 19). به

\footnotetext{
3 . Augmented Feedback

${ }^{4}$. self-modeling

${ }^{5}$. self-controlled feedback

6 . feedback after successful

7 . "good" trials

${ }^{8}$. positive social comparison

${ }^{9}$. entity theorists

${ }^{10}$. incremental theorists
}

https://jrsm.khu.ac.ir/ 
خصوص برخى از اين مطالعات نشان دادند كه بازخورد كلامى اين بتانسيل را دارد كه، مفهوم توانايى از ديدكاه كودكان را تحت تأثير قرار دهد كه با نتايجى از قضاوت فرد درمورد ثبات خصوصيات شخصى در طول زمان يا زمينها و عكس العمل هايى در يادگيرى و عملكرد مرتبط است. بازخورد عام و خاص رابطه مستقيمى با نوع توانيى فرد دارد، بازخورد خاص به يك رويداد خاص اشاره مى كند و اجراى تكليف به دليل قابليت اكتساب مهارت مىباشد و نشان مىدهد كه عملكرد قابل انعطاف است، در حالى كه بازخورد عام يك عملكرد ذاتى را نشان مىدهد. يافتهاى كلمان و همكاران (1999) نشان داد كه كودكان مىتوانند ويزگگىهاى ديخر افراد كه در طول زمان ثابت مىمانند و به صورت يك اسم بيان مى شوند، را بهتر درى كنند (به عنوان مثال او سحر خيز است) در مقايسه با زمانى كه به صورت يك جمله خبرى بيان

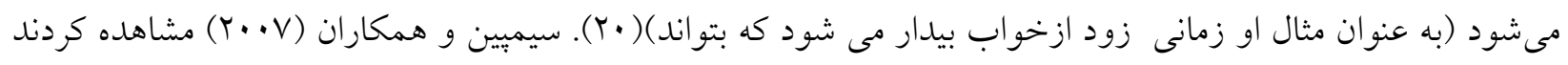
كه كودكان به نوع تشويق با توجه به رفتار خود، حساس هستند( (Y). نويسندكان نتيجه كرفتند كه بازخورد عام مىتواند نتيجه فكر كودكان در دوره هاى كوششى باشد مثلاً اينكه اشتباهات را به عنوان توانايى پايين يا يكى صفت منفى تفسير

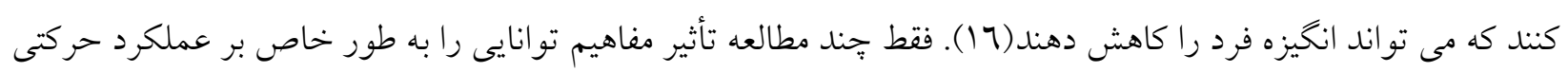
و زمينه هاى يادگيرى مورد بررسى قرار دادند و تمام اطلاعات در قالبى از دستور العمل به منظور استنتاج ديدگاههاى

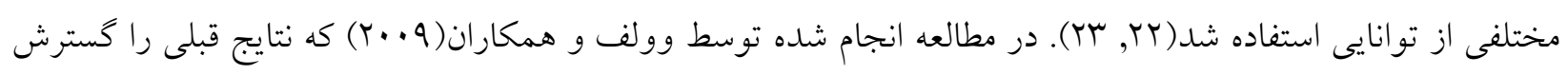

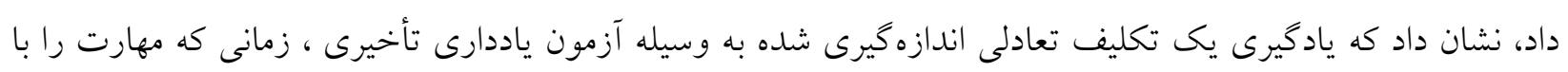
دستورالعمل قابل دست يافننى به جاى القاى آن به عنوان يك مهارت با توانايى ذاتى نشان دهند، افزايش مى يابد(بآ). اخيرا دريوز و همكاران (r|r(Y) اين نتايج را به كودكان با سنين مختلف در حالى كه يك تكليف برتابى را ياد مى گرفتند،

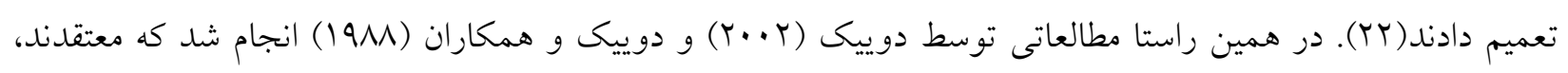
بازخورد خاص اين يتانسيل را دارد كه در كودكان باعث اين شود كه بعد از انجام خطا و اشتباه تلاش بيشترى براى

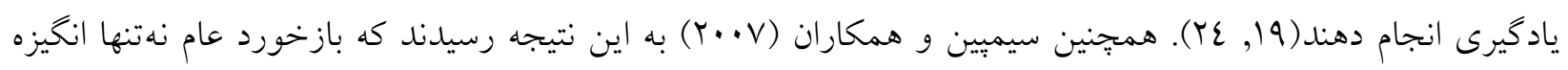
درونى را مىتواند كاهش دهد بلكه عملكرد حركتى را در مقايسه با بازخورد خاص كاهش مىدهد(·r). تحقيق ديخرى در همين راستا توسط جيوياكوفسكى و همكاران (ع) (Y) به منظور بررسى اينكه آيا اطلاعاتى كه از بازخورد دريافت مى شود برداشت هاى متفاوتى از توانايى را نشان مى دهد؟ انجام شد، به اين نتيجه رسيدند كه بازخورد عام و خاص هر دو موجب افزايش يادكيرى مىشوند با اين تفاوت كه بازخورد خاص يادكيرى بهترى نسبت به بازخورد عام ايجاد مىكند(1) (1). با توجه به اهميت مفهوم توانايى در يادكيرى حركتى، يزوهشهاى كمى تأثير مفهوم توانايى را توسط بازخورد عام و خاص بر يادكيرى حركتى كودكان بررسى كرده اند. همجنين بررسى تأثير مفهوم توانيى توسط بازخورد عام و خاص بر انخيزش درونى و خرده مقياس هاى آن از اهميت خاصى برخوردار است زيرا انخيزه درونى به عنوان محرى و 
تشويق كننده افراد براى يادكيرى و بهبود اجرا در نظر گرفته مى شود. بنابراين هدف از اين مطالعه بررسى تأثير بازخورد

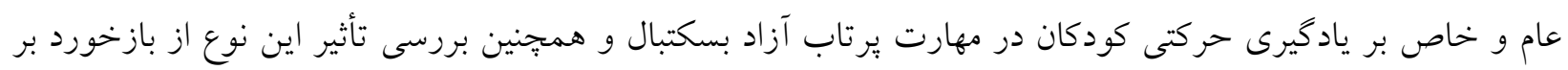
جنسيت كودكان نيز مى باشد.
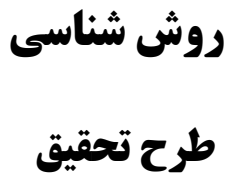

اين نوع تحقيق به دليل مداخله محقق بر متغير مستقل و انتخاب تصادفى آزمودنىها از نوع نيمه تجربى و طرح تحقيق از نوع سرىهاى زمانى بود.

\section{جامعه و نمونه آمارى}

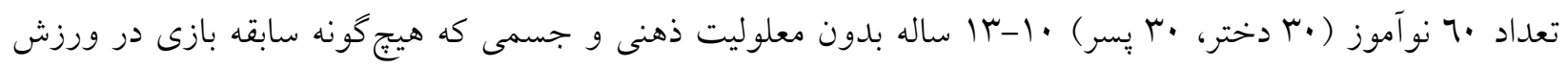
بسكتبال نداشتند از ميان دانش آموزان شهر تهران از يكى مجموعه ورزشى انتخاب شدند. شركت كنند كان به صورت تصادفى در جهار گروه (10 دختر بازخورد خاص، 10 ادختر بازخورد عام؛ 10 يُر با بازخورد خاص، 10 يُسر بازخورد عام) به طور تصادفى قرار خرفتند.

ابزار تحقيق

از سبد و توبٍ استاندارد با سايز 0 كه متناسب با سن آزمودنى ها بود، استفاده شد براى بررسى دقت يرتاب آزاد بسكتبال

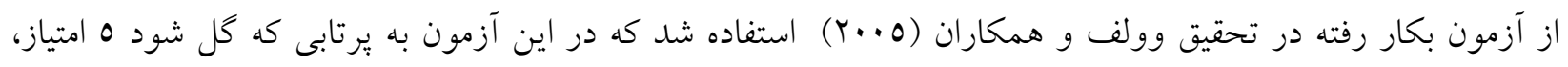
برخورد توب به حلقه r امتياز، برخورد توبٍ به تخته و حلقه r امتياز، برخورد توبٍ به تخته ا امتياز و يرتاب ايربال (بدون برخورد به حلقه و تخته) صفر امتياز تعلق كرفت(Y0).

\section{روش اجراى آزمون}

نخست از آزمودنىها خواسته شد كه فرم رضايت نامه اخلاقى و اطلاعات فردى را بر كنند. سبس شركت كنندها توسط

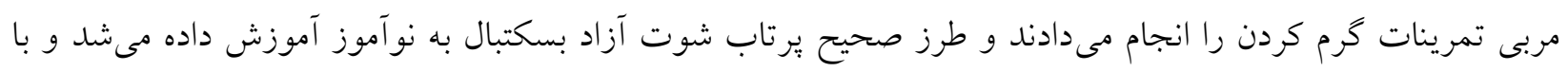
انجام ينج يرتاب تمرينى، روند اجراى كار را آغاز مىكردند. براى اين كار يك توبٍ متناسب با سن شركت كنند كان تهيه

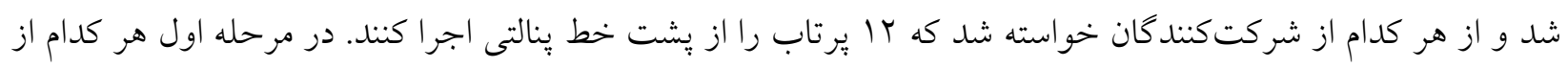
شركت كنند كان سه يرتاب انجام مى دادند كه بعد از اين مرحله هر يك با توجه به كروهى كه در آن قرار داشت بازخورد 
عام (تو يك بسكتباليست خوب در آينده خواهى شد) يا بازخورد خاص (آخرين شوت تو ، بهترين شوت تو خواهد شد) دريافت مى كردند. در مرحله دوم آزمايش سه برتاب ديخر را انجام دادند كه بعد از آن يك بازخورد منفى (اين برتابهاى تو خيلى دقيق نبودند) دريافت كردند (دليل استفاده از بازخورد منفى براى بيى بردن به ماندگارى أثر بازخورد مثبت بود)(17 ). در مرحله سه كه بعد از •ب دقيقه انجام شد و به عنوان مرحله ياددارى شناخته شد هر شركت كننده شش يرتاب انجام داد كه هيج كونه بازخوردى دريافت نكردند(1 (1).

\section{روش هاى آمارى}

براى توصيف دادهها، ميانخين و انحراف معيار از آمار توصيفى استفاده شد سبس براى تعيين طبيعى بودن توزيع دادهها از آزمون شاييرووييك و براى بررسى تجانس گروهها از آزمون لوين استفاده شد. براى بررسى تفاوت بين گروهها از آزمون تحليل واريانس دوعاملى و آزمون تعقيبى توكى و همجنين براى بررسى تفاوت درون گروهى از آزمون تحليل واريانس

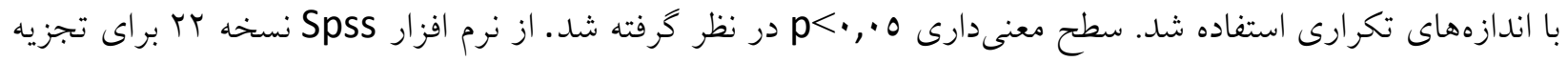
و تحليل دادها و از نرم افزار Excel نسخه با بأبراى رسم نمودارها استفاده شد.

\section{نتايج}

جدول يك ميانگين نمرهى برتابهاى مراحل اكتساب و ياددارى كودكان براى اجراى برتاب آزاد بسكتبال در جهار گروه (10 دختر بازخورد خاص، 10 دختر بازخورد عام؛ 10 يُر با بازخورد خاص، 10 يُر بازخورد عام) نشان داده شده است.

جدول ا - ميانگين و انحراف معيار نمره هاى يرتاب آزاد بسكتبال در جهار گروه

\begin{tabular}{|c|c|c|c|}
\hline تعداد & انحر اف معيار & ميانخين & كروه ها \\
\hline 10 & $V, Y \wedge O$ & $r r, q r$ & دختر (بازخورد عام) \\
\hline 10 & $\Lambda, r \cdot 1$ & $\mu_{1,7 .}$ & دختر ( بازخورد خاص) \\
\hline 10 & 9,107 & $r \varepsilon, T V$ & يسر (بازخورد عام) \\
\hline 10 & $v, 771$ & $r_{0}, \varepsilon$. & بسر (بازخورد خاص) \\
\hline
\end{tabular}

https://jrsm.khu.ac.ir/ 
مر حله اكتساب

آزمون تحليل واريانس مختلط با اندازه كيرى مكرر در مرحله اكتساب، أثر بلوكهاى تمرينى را معنادار نشان داد (0 ( •>p). يعنى تمامى گروهها توانستهاند در مرحله اكتساب با استفاده از كوششهاى تمرينى بر دقت عملكرد خود اضافه كنند. برترى در مرحله اكتساب نيز با گروه يّر بازخورد خاص بود( ( +.,

جدول r. اندازههاى تكرارى مرحله اكتساب

\begin{tabular}{|c|c|c|c|c|}
\hline خروه بسر -بازخورد & گُروه بسر - بازخورد & خروه دختر-بازخورد & كروه دختر -بازخورد & كروه ها \\
\hline$\cdot, \cdots 1$ & $\cdot, .00$ &., 11 & $\because \cdot r q$ & P P P \\
\hline $10,9 Y 1$ & $\varepsilon$, rVo & $\Lambda, 0 \sum Y$ & $7,17 \pi$ & F ارزش \\
\hline
\end{tabular}

مر حله ياددارى

براى مشخص كردن أثر جنسيت و نوع بازخورد در ميان كروهها از آزمون تحليل واريانس دوعاملى استفاده شد كه أثر

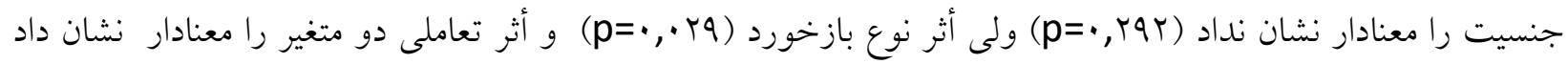
$(p=\cdot, \cdot 7)$

جدولr. آزمون تحليل واريانس دوعاملى

\begin{tabular}{|c|c|c|c|c|}
\hline P ارزش & Fقدار F & درجه آزادى & ميانخين مجذورات & عامل ها \\
\hline$\cdot, \cdot \mathrm{rq}$ & $0, \cdots 1$ & 1 & . & أثر نوع بازخورد \\
\hline$\cdot$, rar & $1,|\pi|$ & 1 & $V \varepsilon, \wedge I V$ & أثر جنسيت \\
\hline \multirow[t]{3}{*}{$\cdot, \cdot 7$} & N, rOY & 1 & $0 \varepsilon 7, \cdot 1 V$ & أثر تعاملى \\
\hline & & 07 & 77,179 & خطا \\
\hline & & 7. & & كل \\
\hline
\end{tabular}

https://jrsm.khu.ac.ir/ 
همجنين براى بررسى سطح بيشرفت فراكيران در مرحله ياددارى از آزمون تحليل واريانس با اندازههاى تكرارى استفاده

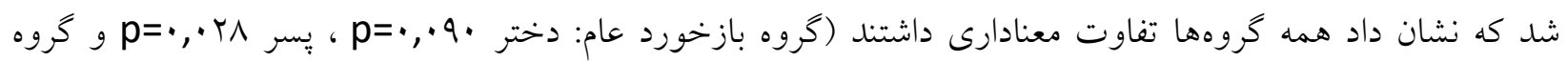

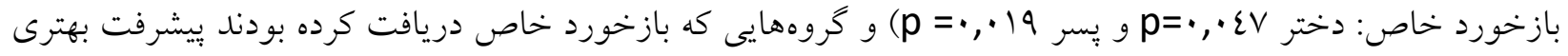
نسبت به كروههايى كه بازخورد عام دريافت كرده بودند، داشتند.

جدول أ. آزمون اندازهاى تكرارى مرحله ياددارى

\begin{tabular}{|c|c|c|c|c|}
\hline خروه بسر -بازخورد & گرُوه يسر - بازخورد & خروه دختر-بازخورد & كروه دختر -بازخورد & كروه ها \\
\hline$\cdot, .19$ & $\cdot, \cdot\lceil\Lambda$ & $\cdot, \cdot \varepsilon V$ & 0,9 & P P P \\
\hline$\varepsilon, q \pi\rceil$ & $0,9 \wedge r$ & $r, \pi 7 r$ & $r, Y I r$ & F ارزش \\
\hline
\end{tabular}

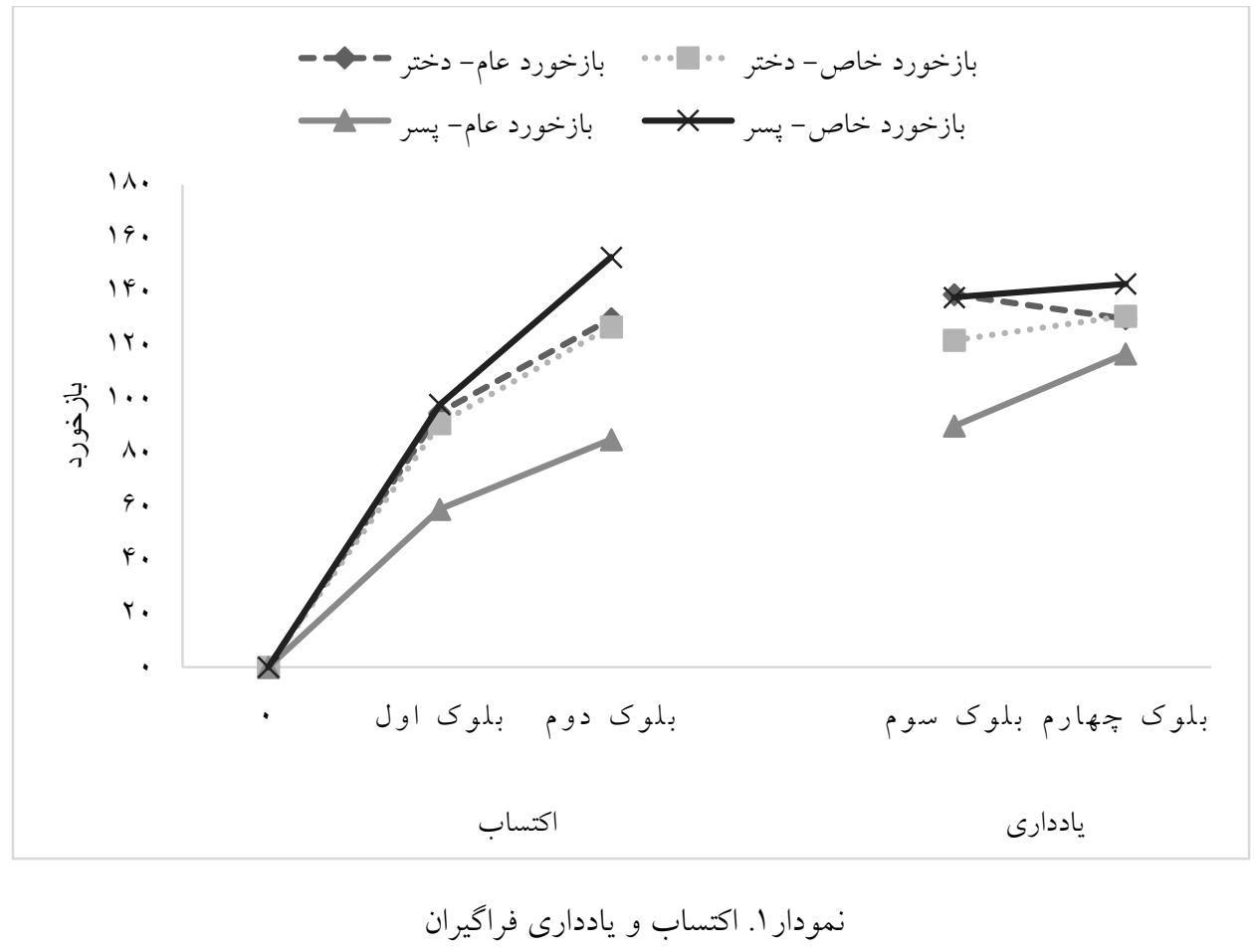

https://jrsm.khu.ac.ir/ 


\section{بحث و نتيجه كيرى}

مطالعات اخير نشان دادند كه بازخورد مىتواند بر يادكيرى حركتى كودكان مؤثر باشد، اين تأثير نه تنها به وسيله فراهم

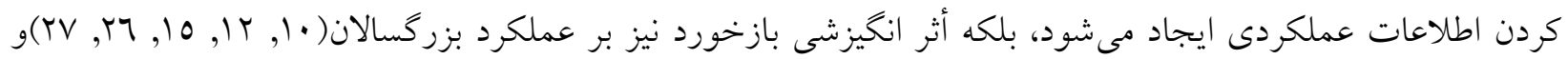

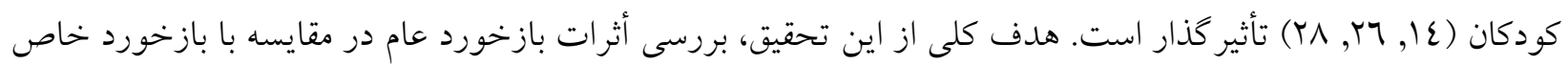
بر اكتساب و ياددارى يرتاب آزاد بسكتبال كودكان بود. فرض ما اين بود كه دريافت بازخورد خاص در مقايسه با بازخورد عام به ويزه بعد از يك بازخورد منفى، براى شركت كنندكان بهتر خواهد بود كه با توجه به نتايج بدست آمده، مورد تاييد قرار كرفت. با توجه به اينكه ارائه بازخورد مثبت به عنوان يك استراتزى خوب براى بيشرفت يادكيرى حركتى مشاهده شده است با اين حال، يافتهاى حاضر نشان مىدهد كه برخى از انواع بازخورد مثبت ممكن است مطلوب نباشند به خصوص زمانى كه افراد نياز دارند با شكست مقابله كنند. مفهوم ظريفتر ارائه شده توسط بازخورد عام، تاكيد كردن به ظرفيت ثابت توانايىها مىباشد و بازخورد خاص، معتقد به انعطافيذيرى در توانايى است. ظاهراً يادگيرى حركتى از راههاى مختلفى تحت تأثير قرار مى كيرد به خصوص در مقايسه با زمانى كه اطلاعات به صورت مستقيم در قالب دستور العمل ارائه مىشوند. شركت كنند كانى كه در مطالعه حاضر بازخورد عام دريافت كرده بودند، (شامل تكليفى مىشد كه منعكس كننده مفاهيم توانايى ذاتى بود) مفاهيم توانايى اكتساب مهارت را دريافت كردند به طورىكه أثرات آن نه تنها با عملكرد حركتى بلكه با يادكيرى حركتى نشان داده شد، عملكرد ضعيفترى نسبت به شركت كند گانى كه بازخورد خاص دريافت كرده بودند، داشتند. در مراحل تمرين همه گروهها بيشرفت داشتند ولى گروههاى بازخورد خاص بيشرفت بهترى نسبت به بقيه گروهها داشتند. در تفسير برترى بازخورد خاص، مىتوان كفت جون يكى از ويزگى هاى بازخورد، نقش انكيزشى آن است بنابراين آكاهى از اجرا و نتيجه، تكليف را جالبتر مى كند، يادكيرنده را آكاه مىسازد و موجب مى شود ياد كيرنده اهداف اجرايى بالاترى را تنظيم كند. همجنين فراخيران از بازخورد به عنوان اطلاعاتى براى انجام حركت بعدى خود استفاده مى كنند و مى توانند بازخورد دريافت شده از يك كوشش را با برنامهى حركتى تعميم يافته ارتباط دهند( الب). به هر حال نتايج حاضر با ديدكاه نظريهابردازان ذاتى (تلاش براى ثابت نخه داشتن توانايىها با عملكرد بهتر نسبت به ديخران) هم راستا هستند، درحالى كه نظريهإيردازان تكاملى (تلاش براى بهبود دادن تكليف) به افزايش انخيختى

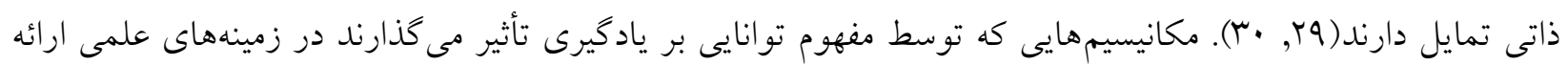

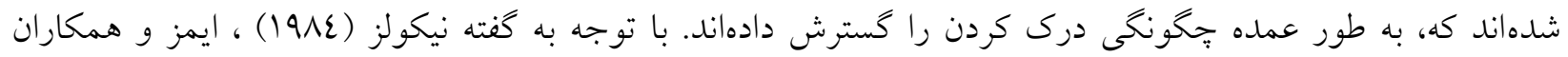

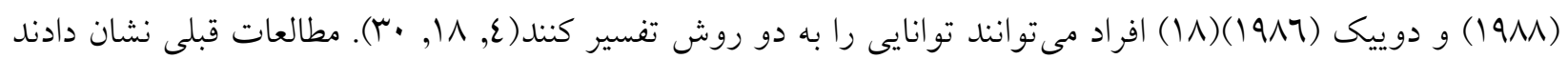
كه يك ديدگاه قابل يادكيرى يا قابل انعطاف وجود دارد كه به افزايش خودكارآمدى، كاهش عصبانيت و افكار درمورد توانايى خود، توجه كمتر در ارتباط با حركات بدن و خودكارى بيشتر در كنترل حركات بستخى دارد و به عنوان ديدكاه 


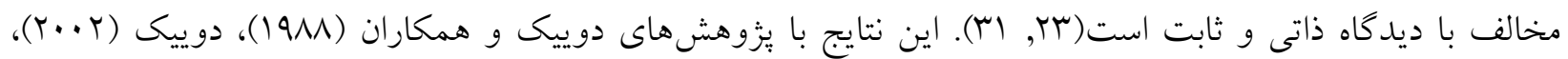

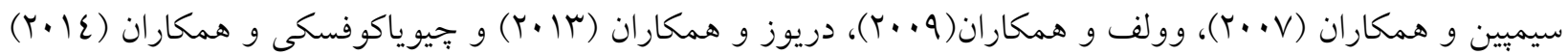
هم راستا مىباشند. در رابطه با أثر جنسيت در اين بزّوهش با توجه به بررسىهايى كه انجام شد، برترى گروه يسران را در

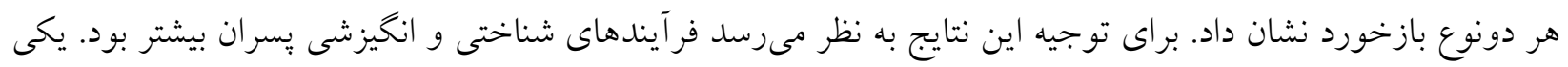
از علل تفاوتهاى جنسيتى با توجه به يزوهشهاى ييشين مىتواند مربوط به باورهاى كودكان نسبت به موفقيت و شكست خود باشد. بنابراين دختران اولين علت را به عدم توانايى بيشتر در مواقع شكست نسبت به يسران مىدانند. علت دوم آن است كه دختران بيشتر از اينكه موفقيتشان را به توانايى خوب نسبت بدهند، علت شكستشان را به توانيى كم نسبت مىدهند(r|). روى هم رفته اين نتايج نشان مى دهد كه دختران بيشتر از يسران، علت شكست خود را درونى مىدانند(·r).

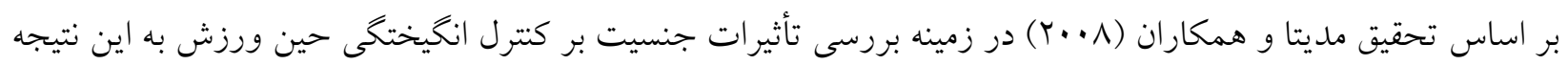
رسيدند كه مردان در مقايسه با زنان كنترل بهترى بر انخيختكى خود دارند و همجنين اين نتايج با تحقيقاتى كه تو سط فاريس و همكاران (س4911) و كراندال و همكاران (1970) انجام شد، همراستا مىباشند. با توجه به نتايج تحقيق در ارتباط با سودمندى بازخورد خاص نسبت به بازخورد عام، به نظر مىرسد جنانجه در طى جلسات تمرين به فراخيران بازخورد خاص داده شود تا به كونهاى از خاصيت انعطاف يذيرى تواناييشان استفاده كنند، أثر تمرين افزايش خو اهد يافت و عملكرد بهترى خواهند داشت. در اين يزوهش با توجه به خلأهاى موجود، مطالعات آينده مىتواند به بررسى أثر اين دو نوع بازخورد بر عوامل روانشناختى بيردازند.

1. Schmidt R, Lee T. Motor control and learning 4th ed, 207-242. Human Kinetics Publisher; 2005.

2. Magill RA. Motor learning and control. Concepts and applications. 2004;7.

3. Smith R, Lee T. Motor control and learning: a behavioural emphasis. Champaign :Human Kinetics. 1998 . 4. Schimidt RA. Motor Learning and Performance from Principles to Practice. Illionis: Human Kineticks Publishers Inc. 1991.

5. Adams JA. A closed-loop theory of motor learning. Journal of motor behavior. 1971;3(2):111-50..

6. Ilies R, Judge TA. Goal regulation across time: the effects of feedback and affect. Journal of applied psychology. 2005;90(3):453.

7. Allen J, Howe BL. Player ability, coach feedback, and female adolescent athletes' perceived competence and satisfaction. Journal of sport and exercise psychology. 1998;20(3):280-99.

8. Mouratidis A, Vansteenkiste M, Lens $W$, Sideridis $G$. The motivating role of positive feedback in sport and physical education: Evidence for a motivational model. Journal of sport \& exercise psychology. 2008;30(2):240.

9. Clark SE, Ste-Marie DM. The impact of self-as-a-model interventions on children's self-regulation of learning and swimming performance. Journal of Sports Sciences. 2007;25(5):577-86.

10. Chiviacowsky S, Wulf G. Self-controlled feedback: Does it enhance learning because performers get feedback when they need it? Research quarterly for exercise and sport. 2002;73(4. 1 $0_{-} \varepsilon \cdot \wedge:($ 
11.Patterson JT, Carter M. Learner regulated knowledge of results during the acquisition of multiple timing goals. Human movement science. 2010;29(2):214-27.

12. Chiviacowsky S, Wulf G. Feedback after good trials enhances learning. Research Quarterly for Exercise and Sport. 2007;78(2):40-7.

13.Saemi E, Wulf G, Varzaneh AG, Zarghami M. Feedback after good versus poor trials enhances motor learning in children. Revista Brasileira de Educação Física e Esporte. 2011;25(4):673-81.

14. Ávila LT, Chiviacowsky S, Wulf G, Lewthwaite R. Positive social-comparative feedback enhances motor learning in children. Psychology of Sport and Exercise. 2012;13(6):849-53.

15.Chiviacowsky S, Wulf G, Lewthwaite R. Self-controlled learning: the importance of protecting perceptions of competence. Frontiers in psychology. 2012;3:458.

16. Chiviacowsky S, Drews R. Effects of generic versus non-generic feedback on motor learning in children. PloS one. 2014;9(2):e88989.

17. Ross M. Relation of implicit theories to the construction of personal histories. Psychological review. 1989;96(2):341.

18.Dweck CS. Motivational processes affecting learning. American psychologist. 1986;41(10):1040.

19. Dweck CS, Leggett EL. A social-cognitive approach to motivation and personality. Psychological review. 1988;95(2):256.

20.Gelman SA, Heyman GD. Carrot-eaters and creature-believers: The effects of lexicalization on children's inferences about social categories. Psychological Science. 1999;10(6):489-93.

21.Cimpian A, Arce H-MC, Markman EM, Dweck CS. Subtle linguistic cues affect children's motivation. Psychological Science. 2007;18(4):314-6.

22.Drews R, Chiviacowsky S, Wulf G. Children's motor skill learning is influenced by their conceptions of ability. JMLD. 2013;1:38-44.

23. Wulf G, Lewthwaite R. Conceptions of ability affect motor learning. Journal of Motor Behavior. 2009;41(5):461-7.

24.Dweck CS. The development of ability conceptions. 2002.

25. Wulf G. Self-controlled practice enhances motor learning: implications for physiotherapy. Physiotherapy. 2007;93(2):96-101.

26.Badami R, VaezMousavi M, Wulf G, Namazizadeh M. Feedback after good versus poor trials affects intrinsic motivation. Research quarterly for exercise and sport. 2011;82(2):360-4.

27.Lewthwaite R, Wulf G. Social-comparative feedback affects motor skill learning. The Quarterly Journal of Experimental Psychology. 2010;63(4):738-49.

28. Chiviacowsky S, Wulf G, de Medeiros FL, Kaefer A, Tani G. Learning benefits of self-controlled knowledge of results in 10-year-old children. Research Quarterly for Exercise and Sport. 2008;79(3):40510.

29. Hong Y-y, Chiu C-y, Dweck CS, Lin DM-S, Wan W. Implicit theories, attributions, and coping: A meaning system approach. Journal of Personality and Social psychology. 1999;77(3):58.^

30. Nicholls JG. Causal attributions and other achievement-related cognitions: Effects of task outcome, attainment value, and sex. Journal of Personality and Social Psychology. 1975;31(3):379.

31.Jourden FJ, Bandura A, Banfield JT. The impact of conceptions of ability on self-regulatory factors and motor skill acquisition. Journal of sport and exercise psychology. 1991;13(3):213-26. 